\title{
Influence of different forest protection strategies on spruce tree mortality during a bark beetle outbreak
}

\author{
Pavel Mezei $^{1}$ • Miroslav Blaženec ${ }^{1}$ - Wojciech Grodzki ${ }^{2}$ Jaroslav Škvarenina ${ }^{3}$. \\ Rastislav Jakuš ${ }^{1,4}$
}

Received: 7 November 2016 / Accepted: 6 September 2017 / Published online: 27 September 2017

(C) INRA and Springer-Verlag France SAS 2017

\section{- Abstract}

\section{- Key message}

Under an outbreak scenario in a buffer zone of a protected area, bark beetle-caused tree mortality was modulated by earlier natural disturbances (wind and bark beetles), sanitary management and seasonal temperature. In buffer zones, the effects of sanitary management on tree mortality remained limited due to the migration of bark beetles from unmanaged areas.

\section{Handling Editor: Aurélien Sallé}

Contribution of the co-authors

Pavel Mezei: designing the experiment, running the data analysis, writing the paper

Miroslav Blaženec: data gathering, designing the experiment, coordinating the research project

Wojciech Grodzki: data gathering, designing the experiment, comments on manuscript

Jaroslav Škvarenina: climate data gathering, comments on manuscript Rastislav Jakuš: data gathering, designing the experiment, supervising the work

This paper is part of the Topical Collection: 'Risk Analysis'

\section{Pavel Mezei}

mezei@savzv.sk

Miroslav Blaženec

miroslav.blazenec@gmail.com

Wojciech Grodzki

W.Grodzki@ibles.waw.pl

Jaroslav Škvarenina

jaroslav.skvarenina@tuzvo.sk

\section{- Context}

The European spruce bark beetle (Ips typographus L.) is regarded as an economically significant pest of Norway spruce (Picea abies [L.] Karst). However, in protected areas, it is regarded as a keystone species for biodiversity. This results in two contrasting management strategies that meet in buffer zones of protected areas.

\section{- Aims}

To assess which environmental and management variables are most important for tree mortality in an ongoing bark beetle

Rastislav Jakuš

rasti.jakus@gmail.com

Institute of Forest Ecology, Slovak Academy of Sciences, Štúrova 2, 96053 Zvolen, Slovak Republic

2 Department of Mountain Forests, Forest Research Institute, ul. Fredry 39, 30-605 Kraków, Poland

3 Faculty of Forestry, Technical University, Zvolen, Slovakia

4 Department of Forest Protection and Game Management, Faculty of Forestry and Wood Sciences, Czech University of Life Sciences, Kamýcká 1176, 16521 Praha 6 - Suchdol, Czech Republic 
outbreak and to gain a better understanding of the challenges and recommendations for buffer zone management under the influence of nearby unmanaged stands in a protected area.

\section{- Methods}

Norway spruce tree mortality was assessed in 419 forest stands in the High Tatra Mountains. To account for spatial and temporal autocorrelations, generalized additive mixed models (GAMM) were used, and an information-theory (IT) approach was adopted for model selection to test the influence of environmental variables, natural disturbances and the previous year's sanitary cutting on bark beetle-caused tree mortality.

\section{- Results}

In buffer zones, $P$. abies tree mortality caused by $I$. typographus was positively correlated to natural disturbances and sanitary cutting in the previous year.

\section{- Conclusion}

The previous year's sanitary cutting, maximum temperature sums, wind disturbance and trees left in no-intervention stands contributed to tree mortality in buffer zones. In these zones, the decrease of tree mortality in response to sanitary management remained limited due to the migration of bark beetles from unmanaged areas. However, sanitary management in buffer zones remains necessary for the isolation of bark beetle outbreaks in unmanaged areas.

Keywords Picea abies · Ips typographus · Disturbance · Temperature $\cdot$ Wind $\cdot$ Protected area

\section{Introduction}

Spruce forests (Picea abies [L.] Karst] in the Carpathian Mountains in Central and Eastern Europe are shaped by infrequent disturbances, ranging in severity from low (e.g. single trees or groups) to high (stand-replacing). The main drivers of such disturbances are windthrows and bark beetle outbreaks (Holeksa et al. 2016; Nikolov et al. 2014; Svoboda et al. 2014; Trotsiuk et al. 2014). Bark beetle outbreaks are usually initiated by extensive wind disturbance or extreme weather events. Active regeneration and enhanced biodiversity demonstrates the large resilience of these ecosystems towards such events (Jonášová et al. 2010; Beudert et al. 2015; Nováková and Edwards-Jonášová 2015; Thom et al. 2016; Thorn et al. 2017). However, bark beetle outbreaks are associated with significant ecological changes, as well as economical damage in managed forests, making bark beetles the most important forest pest in temperate zones (Raffa et al. 2015). Forest managers traditionally implement intensive preventive measures (active management) to mitigate bark beetle threats in commercial or managed forest stands. These measures commonly comprise the rapid removal of wind-felled trees (salvage logging), as well as the removal of infested standing trees next to windthrows or newly appeared infestation spots (sanitary cutting) (Stadelmann et al. 2013a). These efforts are focused on maintaining bark beetle populations at an endemic level. During bark beetle outbreaks, sanitary strategies are similar to preventive strategies. Measures are focused on the early detection and removal or debarking of bark beetle-infested trees. In some regions, barriers of pheromone traps are used to support the control of bark beetles. Many pheromone traps are installed along fresh forest edges, which attract bark beetles (Jakuš 1998). In contrast, a no-intervention strategy is predominantly followed in core areas of national parks in strict conservation reserves (Grodzki et al. 2010), where bark beetles are considered keystone species (Müller et al. 2008). Attacked and windfelled trees are left in the forest as a biological legacy (Wild et al. 2014; Bače et al. 2015; Macek et al. 2016) and as a major seedbed for $P$. abies seedling recruitment (Zielonka 2006; Svoboda et al. 2010; Bače et al. 2012), although wind-felled or already- attacked trees contribute to new infestations (Økland et al. 2016).

The no-intervention strategy is often applied near commercial spruce forests. The development of bark beetle populations in unmanaged versus managed forests is still a subject of controversy (Markovic and Stojanovic 2010; Müller 2011; Švajda et al. 2016; Lindenmayer et al. 2017). Sproull et al. (2017) compared bark beetle-caused tree mortality in neighbouring stands under active and no-intervention protection regimes, and concluded that active bark beetle management is not effective around unmanaged forests. However, the effect of the location of individual protection zones in altitudinal ranges, as well as bark beetle migration from unmanaged zones, was not considered (Grodzki 2016). This is particularly relevant in cases of large bark beetle outbreaks (Keskitalo et al. 2016; Montano et al. 2016). The effectiveness of active management to contain outbreaks can be hindered by the close proximity of no-intervention zones. In the case of extensive bark beetle outbreaks, this dichotomy can enforce drastic management measures, such as large clear-cuts due to sanitary cuttings around unmanaged areas (Grodzki et al. 2006), usually referred to as "buffer zones". Buffer zones have been established around nature conservation areas to safeguard protected areas from the surrounding managed ecosystems (Shafer 1998). In the case of bark beetle epidemics in the core zone of a national park, these buffer zones can act as a bulwark against the spread of bark beetle infestations into managed forests. However, removal of wind-thrown trees can alter successional pathways compared to no-intervention areas (Michalová et al. 2017; Thorn et al. 2017); there is pressure from forest owners outside the park to stop or slow the spread of bark beetle outbreak leading to bark beetle suppression in 
the buffer zone. The highest intensity of sanitary management will usually focus on this area.

The question of whether the forest management adopted in several European national parks following natural disturbances (windstorms, bark beetle) is, in the long term, the optimal strategy is currently widely discussed (Müller 2011; Dickie et al. 2014; Grodzki 2016; Zýval et al. 2016; Hilszczański and Starzyk 2017). National park zoning and appropriate management of natural stands of mountain spruce is often a key issue (Dickie et al. 2014; Grodzki 2016; Zýval et al. 2016). Instead of a clear management policy, however, only non-compulsory recommendations are suggested and management directives are missing. In the absence of such guidance, park managers adopt various suboptimal strategies, which depend on who owns a particular area of the forest and on their priorities (Zýval et al. 2016). These discussions prioritise a zonation model, which foresees a bark beetle control (buffer) zone of varying width around the no-intervention zones of the protected areas. This management approach will not compromise the no-intervention philosophy in the core zone of these areas, while at the same time providing sufficient protection to surrounding landowners and their managed forests (Dickie et al. 2014).

Our study area, the eastern part of the High Tatras, is located on the border between Slovakia and Poland and comprises part of two national parks: Tatranský Národný Park (TANAP) on the Slovak side and Tatrzański Park Narodowy (TPN) on the Polish side. Disturbance patterns in the northern part of the Tatras differ from those in the southern part. In the northern part, small-scale disturbances prevail (Grodzki and Guzik 2009), whereas in the southern part, stand-replacing disturbances repeatedly occur as a consequence of large windstorms (Zielonka and Malcher 2009; Szewczyk et al. 2011). From 1990 to 2000, a bark beetle outbreak occurred in the northeastern part of the High Tatra Mountains. The outbreak began in 1993, and culminated in 1995-1996 (Grodzki et al. 2006). Differentiated or partially dichotomous management strategies were applied within the outbreak area during the study period of 1990-2000. Management in the Polish portion of the area remained the same throughout the study period; $52 \%$ of the area was subjected to strict (passive) protection, where no human activity, including sanitary management, was permitted. The remaining $48 \%$ of the area was in an active protection zone, where classic sanitary management, mainly sanitary cutting, was practiced. In the Slovak portion of the study area, approaches to sanitary management were modified during individual outbreak phases. Prior to 1994, there was no management; then, in 1995-1996, intensive management (trap trees, insecticides, sanitary cutting) was applied. After 1997, management was differentiated according to the conservation values of the stand, and ecosystem sensitivity was used to define the management strategy: from 'no management' to intensive salvage cutting and intensive application of pheromone trap barriers (Jakuš 1998; Grodzki et al. 2006; Grodzki et al. 2010). After 2000, a strict nature conservation model was applied in the High Tatras, where no-intervention management was prescribed for strict conservation reserves (creating the core zone of national park). A second bark beetle outbreak began in 2002 .

There is still a lack of information regarding the role of forest management in the case of bark beetle epidemics in protected areas, particularly whether the effect of ongoing changes in the ecosystem caused by primary disturbance is stronger than the stand and site features of the location. In our study area, modifications to sanitary management strategies during epidemics in 1990-2000 were applied on the presumption that sanitary cutting and salvage logging led to the containment of the epidemic outbreaks. Netherer and NoppMayr (2005) developed a predisposition assessment system based on site- and stand-related criteria for bark beetle infestation hazards in the study area. Mezei et al. (2014a, 2014b) analysed influence of stand and site variables on bark beetle infestations initiation and spreading. A wind-bark beetle disturbance regime was described, wherein bark beetle populations accumulated after the increase in brood material represented by the trees broken or downed by the wind, which at the same time created new open forest edges with weakened trees for the next wind blowdown and bark beetle attack. This disturbance regime was mainly influenced by stand-related variables, i.e. age (Mezei et al. 2014b). The following initiation of bark beetle infestation was mainly related to the host characteristics. The severity of tree mortality after an infestation began was linked to host characteristics and solar radiation (insolation of trees) (Mezei et al. 2014a).

Given the impossibility of conducting controlled experiments on bark beetle outbreaks and gaining statistically independent replication, new insight must be obtained through observational studies and data gathering throughout the management action (Trzcinski and Reid 2008). Thus, the results of such studies apply mainly to the study area, and broader conclusions must be obtained through repeated studies with similar designs from a variety of study areas.

In this study, we assessed the 11-year trends in bark beetlerelated tree mortality in the active protection zone adjacent to a no-intervention area in the High Tatra Mountains. We used a generalized additive mixed model (GAMM) to determine the effect of sanitary management in actively protected zones. Apart from the variables used in the previous studies (Mezei et al. 2014b), variables related to sanitary management and seasonal weather were added. Specifically, we addressed following questions: (1) which variable group had the largest effect on tree mortality caused by Ips typographus in the actively protected zone? We aimed here to assess the role of the bark beetle populations' pressure and sanitary management in relation to site, stand and weather-related variables. (2) What are the particular effects of the variables selected by the best 
model on annual tree mortality? (3) What recommendations can be derived for the management of buffer zones?

\section{Methods}

\subsection{Study area and data on tree mortality}

The study was conducted in the High Tatra Mountains, the highest mountains in the Carpathians, which extend to $2655 \mathrm{~m}$ a.s.l (Fig. 1). They are located in two national parks: TPN, Poland and TANAP, Slovakia. The study area was located in the north-eastern part of the High Tatras, which are mostly covered by autochthonous $P$. abies forests. Stands were characterised by high altitudinal variability from the lower mountain zone to the timber line, ranging from 900 to $1700 \mathrm{~m}$ a.s.l. Populations of I. typographus in the study area are largely univoltine (Netherer 2003).

Data on yearly tree mortality of $P$. abies per hectare $\left(\mathrm{m}^{3} /\right.$ ha), caused by I. typographus and wind, were obtained by intensive long-term monitoring performed by trained foresters. In our study, we used data spanning an 11-year period (1990-2000). Data were collected and recorded according to forest stands (419 in total), as basic area units throughout the year. The average stand size was 8.5 ha. Unmanaged stands covered 2200 ha, while sanitary-managed stands covered 1388 ha (Fig. 1). In the managed stands, all bark beetleattacked trees were counted and measured after felling for precise calculation of the volume of killed trees. In stands with no management, all attacked trees were marked and counted;

Fig. 1 Study area location in the High Tatra Mountains $\left(49^{\circ} 14^{\prime}\right.$ $39^{\prime \prime} \mathrm{N}, 20^{\circ} 08^{\prime} 22^{\prime \prime}$ E) in Poland and Slovakia. Forest stands with no-management and management are shown

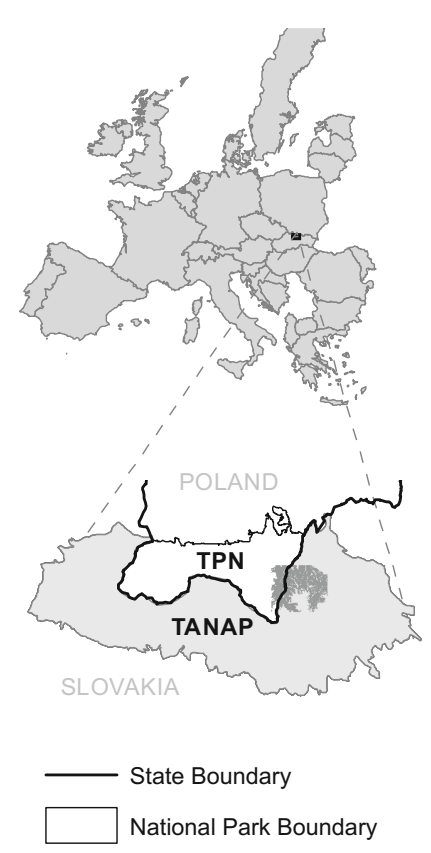

the tree volume was calculated based on forest inventory data (based on average dbh, height and form of trees in each stand). Three basic categories of dead trees were gathered as follows: (i) standing attacked trees (IpsLeft/ha), usually in the unmanaged parts of the study area; (ii) trees attacked by bark beetles and harvested (IpsCut/ha); and (iii) trees killed by wind (Wind/ha) (Grodzki et al. 2006). In the managed stands, wind-felled trees were removed. Winds usually damaged stands during the winter. Damaged trees were usually removed before bark beetle emergence (end of June).

Information related to the distance from unmanaged zones was available, but in the Slovak part of the study area, management strategies were modified several times during the study period. The majority of managed stands were located within $500 \mathrm{~m}$ of unmanaged stands. A distance of $500 \mathrm{~m}$ was considered to be the accepted active migration distance for the establishment of new infestations of I. typographus (Angst et al. 2012; Kautz et al. 2011; Nikolov et al. 2014). The study area is only a small portion of the TANAP (73, 800 ha) and TPN (21, 100 ha). We consider the study areas as unmanaged (core area) and buffer zone (Fig. 1). Stands with management (sanitary and salvage cutting), stands with no management and stands where the management strategy changed during the study period were all included in our analysis.

\subsection{Statistical analysis and model selection}

A set of a priori models (Dochtermann and Jenkins 2011) was selected prior to analysis. These a priori models were

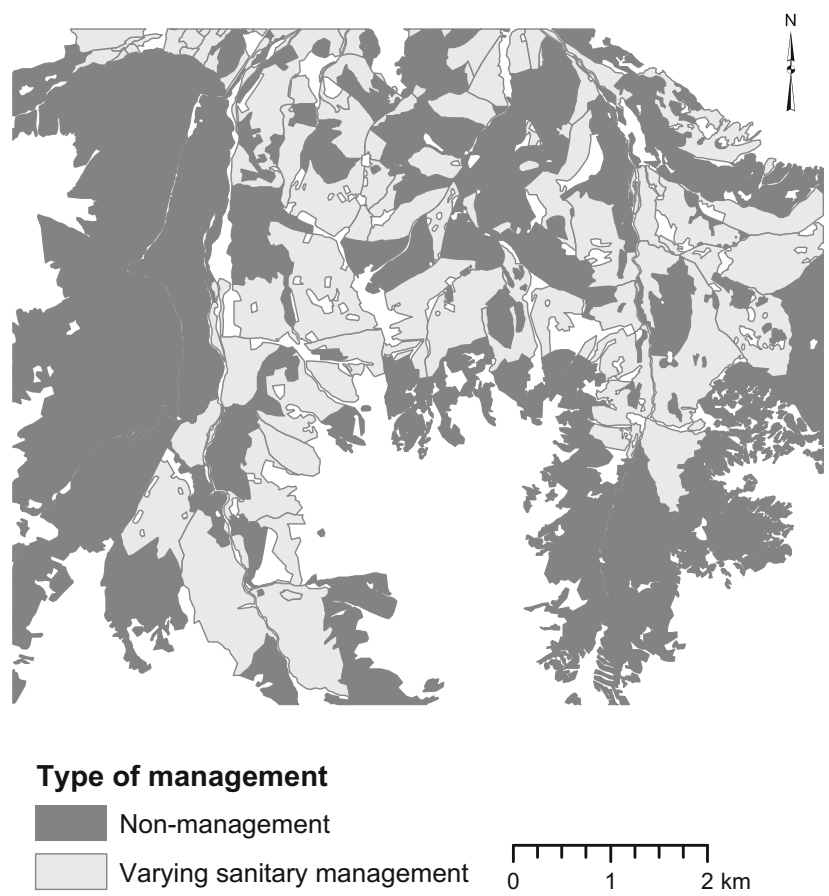


constructed using variables identified previously by different authors (see below) as important to I. typographus population dynamics, or by exploratory analysis and retrospective climate modelling; these comprised stand and site characteristics, temperature conditions in the current or previous year, and management applied (Table 1).

Data for the total volume of trees killed by bark beetles per hectare (IpsSum/ha), i.e. IpsLeft/ha + IpsCut/ha, was used as the response variable. Among the explanatory variables related to previous natural disturbances, we used the volume of trees killed by wind (Wind_1/ha) (Økland et al. 2016) and trees attacked by bark beetles and left in the forest (IpsLeft_1/ha), which represents bark beetle pressure. Sanitary management was represented by the volume of harvested trees in the previous year (IpsCut_1/ha) and the volume of trees harvested in all previous years (IpsCutCumSum/ha). Forest stand characteristics were represented by the age of the stand (Wermelinger 2004; Netherer and Nopp-Mayr 2005; Mezei et al. 2014a). Site characteristics were represented by site class (defined in forest management plans as the potential mean height of the stand at 100 years, according to yield tables) and potential solar radiation derived from a digital elevation model (DEM). Potential solar radiation comprises the effect of slope and exposition (Mezei et al. 2012) and is among the variables affecting I. typographus infestation of trees (Netherer and Nopp-Mayr 2005; Kautz et al. 2013; Mezei et al. 2014a; Sproull et al. 2017). Temperature conditions for each year were represented by the maximum daily air temperature sums from the period of spring swarming of I. typographus to the 31st of October (Mezei et al. 2017). The beginning of spring swarming in each year was calculated using the PHENIPS model (Baier et al. 2007), based on data from a climate station located in the study area. The ATmaxSum was used in two forms, degree days (DD) in the current year (ATmaxSum) and DD in the previous year (ATmaxSum_1).
Data for the coordinates of each forest stand were extracted from a digital elevation model (DEM) for each stand and used as additional explanatory variables (Zeppenfeld et al. 2015). A model with only spatial covariates was added as a baseline. If the baseline model is supported to a similar degree as other candidate models, this would suggest that none of the candidate models is appropriate (Dochtermann and Jenkins 2011). All of the variables were cross-checked for collinearity; in cases where the two-variable correlation exceeded $r=0.50$, only one of the variables was retained. No pair of variables used in the following analysis exceeded $r>0.30$. Because we used previous year tree mortality as an explanatory variable in our analysis, the sample size changed from 11 (1990 to 2000) to 10 years (1991 to 2000).

The information-theory (I-T) approach (Burnham et al. 2011) was used to assess different competing models based on various combinations of predictor variables. Apart from selecting the most parsimonious model, I-T model selection also arranges models in order of parsimony, adding further information on the relative importance of other models in the candidate set (Zuur et al. 2009; Burnham et al. 2011). Models were ranked according to Akaike's information criterion (AIC); the most parsimonious model was selected on the basis of lowest value of AIC (Dochtermann and Jenkins 2011; Rosen 2016). We also calculated delta ( $\Delta$ ) AIC numbers and AIC weights to arrange candidate models in order of parsimony. Models with $\triangle \mathrm{AIC}<2$ can be considered to be as good as the most parsimonious model; those with $\triangle$ AIC values between 2 and 7 should not be rejected completely. Models with $\Delta$ values above 7 have relatively little support. AIC weight is a number from 0 to 1 providing a measure of the relative likelihood of each model, given the data and candidate model set. We avoided using a global model and fitted reduced models instead (Burnham et al. 2011). In the case of more similarly parsimonious models based on $\triangle \mathrm{AIC}$ or AIC
Table 1 Variables used to analyse annual spruce bark beetle-caused tree mortality

\begin{tabular}{|c|c|c|}
\hline Variable & Description & Source \\
\hline$x, y$, & Coordinates of sub-compartments & Digital elevation model \\
\hline Age & Average age of forest stand (years) & Forest management plan \\
\hline Yield class & Potential mean height of the stand at 100 years & Forest management plan \\
\hline PRadiation & Potential global solar radiation $\left(\mathrm{kWh} / \mathrm{m}^{2}\right)$ & Digital elevation model \\
\hline IpsCut_1/ha ${ }^{a}$ & Sanitary felling $\left(\mathrm{m}^{3} \mathrm{ha}^{-1}\right)$ & Forest inventory data \\
\hline IpsCutSum/ha & Cumulative sanitary felling in all previous years $\left(\mathrm{m}^{3} \mathrm{ha}^{-1}\right)$ & Forest inventory data \\
\hline Wind_1/ha ${ }^{\mathrm{a}}$ & Tree mortality caused by wind $\left(\mathrm{m}^{3} \mathrm{ha}^{-1}\right)$ & Forest inventory data \\
\hline IpsLeft_1/ha ${ }^{\mathrm{a}}$ & Tree mortality caused by bark beetles $\left(\mathrm{m}^{3} \mathrm{ha}^{-1}\right)^{\mathrm{b}}$ & Forest inventory data \\
\hline ATmaxSum & Maximum daily air temperature sums (dd-degree days) & Climate station $\mathrm{SHMU}^{\mathrm{c}}$ \\
\hline ATmaxSum_1 $1^{\mathrm{a}}$ & Maximum daily air temperature sums in previous year (dd) & Climate station $\mathrm{SHMU}^{\mathrm{c}}$ \\
\hline
\end{tabular}


weights, a model-averaging process can be used (Burnham et al. 2011).

Candidate models were constructed as generalized additive mixed models because we expected nonlinear relationships between the response and explanatory variables, as well as violations of the independence of measurements taken repeatedly over time and space (Zuur et al. 2009) over the same forest stands. Therefore, we fitted semiparametric models (Keele 2008) implemented in the 'mgcv' package (Wood 2006) for the $R$ statistical language (R 2011) as generalised additive models (GAM). GAMs, in general, excel at detecting the functional form between variables and are a very useful tool for diagnosis or modelling nonlinearity, which is measured by the effective degree of freedom (edf; the higher the edf, the higher the nonlinearity, see Shadish et al. 2014).

We used generalised additive mixed models (GAMM). They allow the inclusion of random effects that can correct for the lack of independence among individuals (Mellor and Cey 2015), i.e., forest stands in our case. I. typographus population dynamics depend on the previous year's level of infestation (Stadelmann et al. 2013b). Therefore, we included a first-order auto-regressive (AR1) correlation structure based on the survey year, along with forest stands, as random effects to model spatial and temporal autocorrelations. A Gaussian distribution, with an identity link function and a thin plate regression smoother, was applied.

\section{Results}

The a priori candidate models are listed in Table 2 . Explanatory variables were grouped into models to represent different aspects of factors affecting I. typographus population dynamics, i.e., to assess whether some factors have higher explanatory power than others.

Only one model from the candidate set fell in the range of $\triangle \mathrm{AIC}<2$ (Table 3). The most parsimonious model was model 6 , which had a $99 \%$ probability of being the best approximating model of tree mortality from the candidate model set, as indicated by Akaike weight (Table 3). Given the large difference in Akaike weights, model-averaging procedures were considered unnecessary and we report only the results of model 6 (Table 4). This model comprised variables related to forest management and climate. Variables that were not included in model 6 were considerably less meaningful to explain annual tree mortality caused by bark beetles. The exclusion of any other model as the most representative for bark beetle infestations, suggesting that site and stand characteristics play a less significant role after an outbreak has been initialized. Models with management only, or models with climate only, were not plausible, i.e. after the occurrence of primary disturbance and outbreak initialization, the size of the bark beetle population and temperature conditions affecting bark beetles and host trees were the most important.
Table 2 Models considered in the study of annual tree mortality of $P$. abies caused by I. typographus. For a description of variables, see Table 1

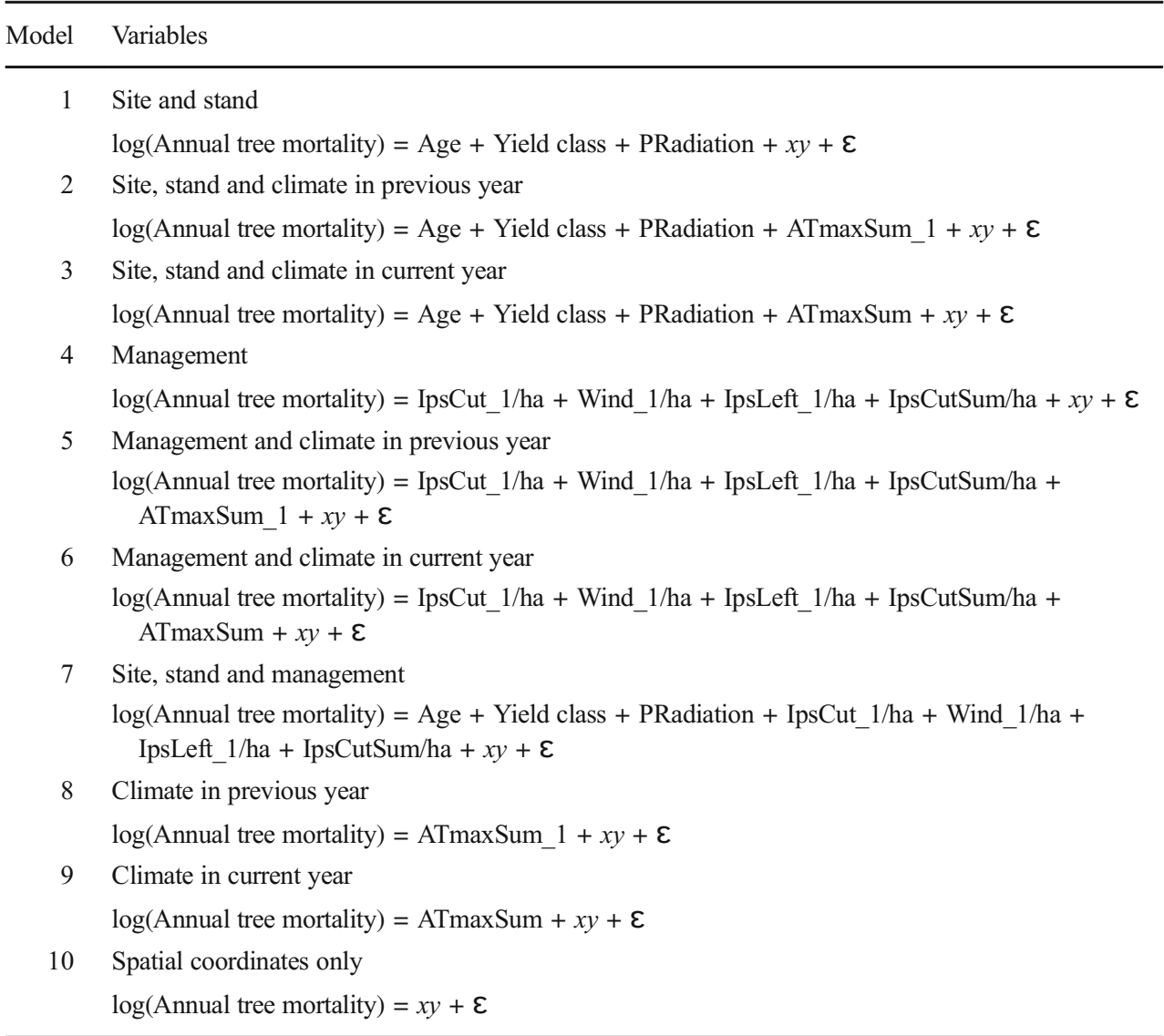


Table 3 Akaike's information criterion (AIC) values, changes in AIC ( $\triangle \mathrm{AIC}$ ) and Akaike weights for models 1-10 listed in Table 2. In this case, no competing model showed $\Delta \mathrm{AIC}<7$, and we report the most plausible model in Table 4 and Fig. $2 \mathrm{a}-\mathrm{e}$

\begin{tabular}{rlcc}
\hline Model & AIC & $\Delta$ AIC & AIC weights \\
\hline 6 & 7839.418 & 0.00 & 0.99 \\
3 & 7906.098 & 66.68 & $<0.0001$ \\
7 & 7921.600 & 82.18 & $<0.0001$ \\
5 & 7956.861 & 117.44 & $<0.0001$ \\
9 & 8019.899 & 180.48 & $<0.0001$ \\
4 & 8025.598 & 186.18 & $<0.0001$ \\
2 & 8033.740 & 194.32 & $<0.0001$ \\
1 & 8120.592 & 281.17 & $<0.0001$ \\
8 & 8143.429 & 304.01 & $<0.0001$ \\
10 & 8223.418 & 384.00 & $<0.0001$ \\
\hline
\end{tabular}

The effects of explanatory variables on annual tree mortality are shown in Fig. 2a-e, while the nonlinearity of the predictor variables for tree mortality caused by the spruce bark beetle are listed according to their effective degrees of freedom (edf; the higher the edf is, the higher the nonlinearity) in Table 4.

Most wind disturbance killed less than $50 \mathrm{~m}^{3}$ of trees per hectare. There was a peak in the volume of trees previously killed by wind (Fig. 2a, Wind 1 / ha), above which the amount of infested trees in the next year declined; however, this mortality curve was pulled down by two observations. The change in the direction of the smoothed curve occurred at approximately $100 \mathrm{~m}^{3} /$ ha. At very high levels of wind disturbance, subsequent tree mortality declined, presumably due to tree depletion in forest stands. The effect of sanitary cutting in the previous year (Fig. 2b, IpsCut_1/ha) was mostly positive, i.e. as more trees that were killed, more trees were infested in subsequent years. The effect of trees infested by bark beetles and left in stands (Fig. 2c, IpsLeft_1/ha) was also positive, but at very high levels of mortality in unmanaged stands, mortality in the subsequent year declined at a similar rate as for cases of

Table 4 Results of the GAMM of the logarithm of annual tree mortality of $P$. abies caused by the spruce bark beetle (Ips typographus) and explanatory variables in the study area from 1990 to 2000 . $R_{\text {adj. }}^{2}=0.38$. The shape of the smooth functions can be observed in Fig. $2 \mathrm{a}-\mathrm{e}$

\begin{tabular}{lcc}
\hline Predictor & Edf $^{\mathrm{a}}$ & $p$ value \\
\hline$x, y$, & 10.5 & $<0.01$ \\
IpsCut_1/ha & 1.93 & $<0.01$ \\
Wind_1/ha & 2.80 & $<0.01$ \\
IpsLeft_1/ha & 3.65 & $<0.01$ \\
IpsCutSum/ha & 3.89 & $<0.01$ \\
ATmaxSum & 3.98 & $<0.01$ \\
\hline
\end{tabular}

${ }^{a}$ Effective degrees of freedom - higher numbers indicate higher nonlinearity wind disturbances, again presumably due to tree depletion. Tree mortality in managed stands (Fig. 2b, $\sim 120 \mathrm{~m}^{3} / \mathrm{ha}$ ) was apparently lower than in unmanaged stands (Fig. $2 \mathrm{c}, \sim 500 \mathrm{~m}^{3} /$ ha) and likely caused by the effect of sanitary cutting, in cases where mortality of trees in subsequent years was kept low.

In contrast, cumulative sanitary cutting (Fig. $2 \mathrm{~d}$, IpsCutCumSum/ha) had a slightly negative effect, i.e. more trees removed from one stand left fewer trees for bark beetle infestations, although this variable is hard to isolate from the effect of bark beetle population pressure. More infested trees in a stand leads to higher cumulative cutting, especially in the neighbourhood of an unmanaged zone. The daily maximum air temperature sum had nonlinear effect on bark beetlecaused tree mortality.

\section{Discussion}

We evaluated the effect of management strategies on the mortality of Norway spruce caused by bark beetle attacks in the buffer zone of a protected area with no-intervention management. Site and stand characteristics play a less significant role after a bark beetle outbreak has been triggered (Mezei et al. 2014a). Similar effects were also observed in managed stands in the Beskid Zywiecki (Grodzki et al. 2014).

Tree mortality was most strongly determined by standing trees killed by bark beetles in the previous year and left in the forest, followed by wind-felled trees. This finding is in line with previous studies from Europe (Kärvemo et al. 2014; Seidl et al. 2015; Økland et al. 2016). Both natural disturbances (wind throws and insect attacks) and previous cutting influenced the likelihood of I. typographus disturbances (Klopcic et al. 2009). In the case of very high amounts of trees killed by wind, the annual tree mortality caused by I. typographus declined. This could be caused by tree depletion by wind (Økland and Berryman 2004; Økland and Bjørnstad 2006) and removal of wind-felled trees in managed stands.

The smooth function of trees killed and removed from the forest also had a positive effect (Fig. 2b), but the volume of trees removed per hectare was much lower than trees killed in the case of unmanaged stands. Stadelmann et al. (2013a) also reported fewer infestations after higher sanitation felling in the managed forest districts of Switzerland (see "Paradox of sanitary cuttings in protected areas" below).

Sanitary cutting, in the long-term, had a negative effect on subsequent bark beetle-caused tree mortality (Fig. 2d), suggesting that precise and timely removal of infested trees is a suitable method to control bark beetle infestation. It is difficult to decouple this variable from the pressure, size and reproduction potential of bark beetle populations in the area. In stands where I. typographus repeatedly occurred, long-term management was not able to suppress beetle pressure, and number of cumulatively removed dead trees reached similar values per 

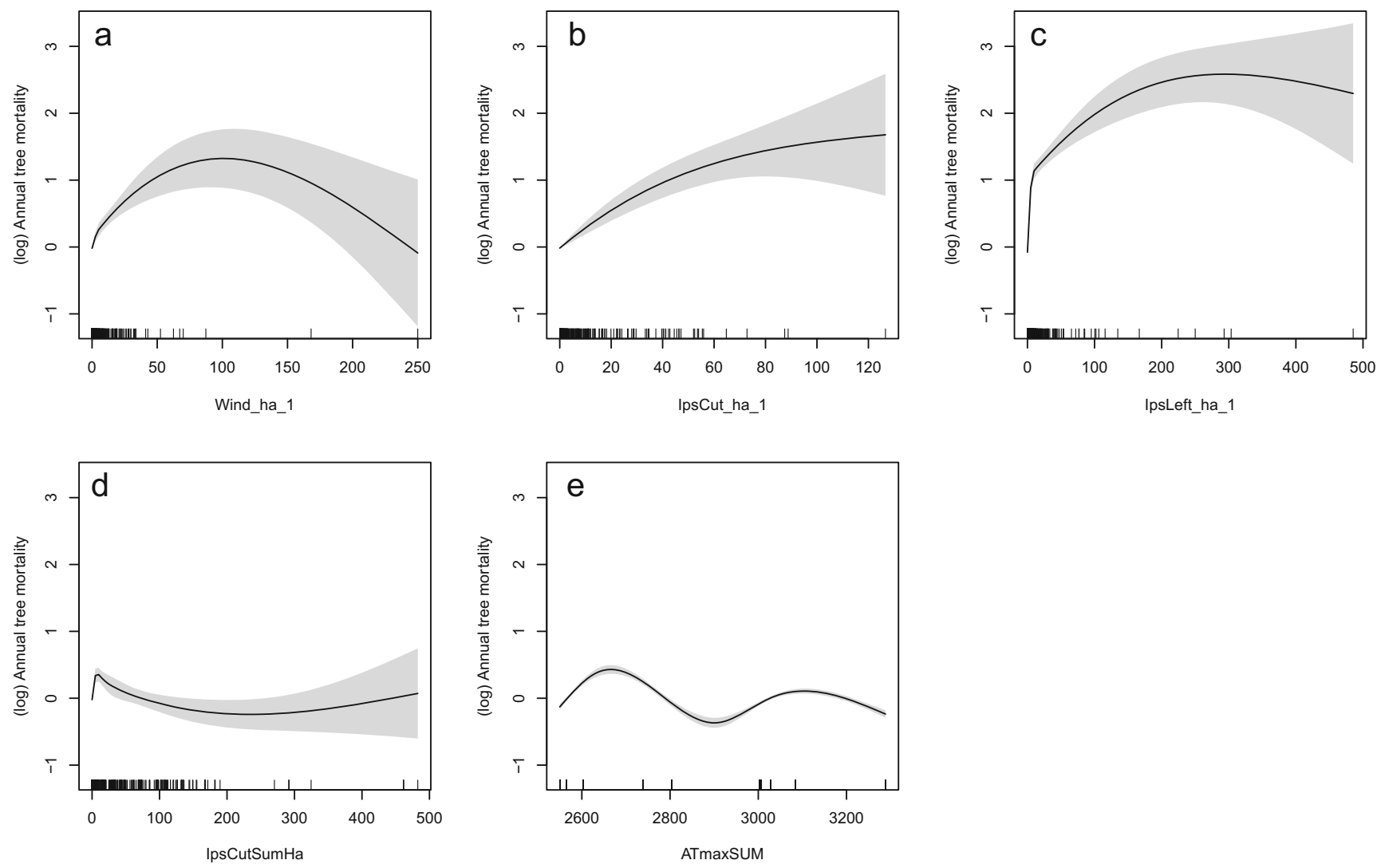

Fig. 2 Smoothed curves of relationship between logarithm of annual bark beetle-caused tree mortality $\left(\mathrm{m}^{3} \mathrm{ha}^{-1}\right)$ and explanatory variables modelled in GAMM. Solid lines are fitted curves, while shaded curves are $95 \%$ confidence intervals. Variables on the $x$-axis are (a) tree mortality caused by wind in the previous year (Wind ha_1), (b) volume of sanitary felling in the previous year (IpsCut_ha_1), (c) tree mortality caused by

bark beetles in the previous year (IpsLeft_ha_1), (d), cumulative sanitary felling in all previous years (IpsCutSum ha), and (e) daily maximum air temperature sums in ${ }^{\circ} \mathrm{C}$ (ATmaxSum). Parameters of the model can be found in Table 4. Each vertical bar at the base of the graph denotes an observation with that value

hectare as in unmanaged stands. Since we did not have managed stands without the influence of unmanaged stands in our sample, it is hard to distinguish whether this was caused by continuous pressure of bark beetles in the buffer zone and from surrounding no-intervention areas, or by the ineffectiveness of long-term management to suppress very high populations of bark beetles.

\subsection{Data limitations}

One factor that may have partially limited the outcomes of our study was the timing of infested tree identification and processing; some trees may have been reported as attacked in the year in which they were cut, but the actual onset of infestation was not known. However, the study was performed in areas of special interest by specially trained foresters and thus the proportion of trees processed very late was low.

Due to legislative and management issues, it was not possible to analyse data from after 2000. Additionally, although data were acquired by specially trained foresters and reviewed by scientific staff, it is not possible to avoid at least some data truncation (Fox et al. 2015). For example, some data points

(bark beetle-attacked trees) may have been missed due to the spatial extent of the study and the extreme terrain. Nevertheless, our approach is not uncommon when data from forestry practices are used (Thom et al. 2013; Pasztor et al. 2014).

We note that our study was not focused on examining spatial effects; thus, we added stand coordinates to our regression equations as interaction terms. Data on tree mortality were aggregated according to forest stands, and therefore some spatial characteristics were lost. For precise spatial aspects, a pixel-based approach is needed, or the position of each tree or bark beetle spot should be gathered. These methods were not available at the time of data collection.

It is important to note that the study area lacked continuously managed stands that were not influenced by bark beetles. The one-to-one comparison of managed vs. unmanaged stands was thus not possible.

\subsection{Paradox of sanitary cuttings in protected areas}

The removal intensity of bark beetle-attacked trees (sanitary cutting) in the previous year (Fig. 2b) was positively related to 
subsequent tree mortality caused by bark beetle infestation; therefore, this parameter mainly reflected the outbreak status. Cumulative sanitary cutting (Fig. 2d) had almost no impact on annual tree mortality. The positive relationship between the previous year's sanitary cutting and the next year's infestation was likely the result of rendering forest stands more attractive to bark beetles, as a result of the primary attraction of bark beetles to logs and new forest edges (Schroeder and Lindelöw 2002; Hedgren et al. 2003; Grodzki et al. 2006; Kautz et al. 2013).

Sanitary cutting is regarded as the most effective method to prevent or control the spread of bark beetle attacks (Wermelinger 2004). However, as soon as bark beetles escape control by management, they are often able to kill nearly all trees, and any management where beetle survival is above 20 $30 \%$ can be ineffective (Fahse and Heurich 2011). Stadelmann et al. (2013a) reported lower bark beetle-caused tree mortality in areas where sanitation felling and efficient salvage logging were conducted. The effectiveness of salvage logging vs. sanitation felling mainly depends on the proportion of wind-felled trees, and sanitation felling was mostly effective in the absence of a large amount of wind damage. The control of beetles in these buffer zones has proven difficult and labourintensive due to the size of the monitored area, as well as the continuing supply of beetles from unmanaged areas (Wermelinger 2004). Moreover, to contain the outbreak, it would be necessary to kill $80 \%$ of the individual beetles based on simulations using the SAMBIA agent-based model (Fahse and Heurich 2011).

A more recent study suggested that bark beetles migrate more from managed stands to unmanaged stands, primarily due to the fast removal of potential breeding substrates in managed stands (Montano et al. 2016). A forest's naturalness can also play a role, as managed stands usually consist of even-aged monocultures, which are more prone to insect outbreaks (Markovic and Stojanovic 2010). However, the migration of bark beetles from unmanaged stands to managed stands, or vice versa, presumably occurs frequently and in both directions. At pre-epidemic levels, bark beetles can more easily move into unmanaged stands because the removal of trees is slower than in an intensively managed buffer zone or in precisely managed stands. However, at later stages (epidemic or post-epidemic), unmanaged zones can host large bark beetle populations and become a strong source of migrating bark beetles (i.e. a hotspot).

The accumulation of a bark beetle population after a windstorm event can take several years (Mezei et al. 2011), during which forest managers have time to take protective steps. Our results suggest that, to a limited extent, continuous sanitary management can influence the volume of infested trees. An additional technique is the intensified use of wind-felled spruce trees as trap trees or the debarking or scratching of stems (Thorn et al. 2016); this technique can be used before the emergence of a new generation of bark beetles in areas that are not in conflict with nature conservation rules. This measure can decrease the density of the bark beetle population attacking the remaining standing trees, especially in the first year after wind disturbance. However, debarking or scratching of a trunk is only possible on a limited scale due to financial costs and the required labour intensity.

\subsection{Effect of windthrow and seasonal temperature sums}

The role of wind in our study was clear: the previous year's windthrows triggered an increase in tree mortality the following year, unless tree mortality by wind exceeded a certain threshold, in which most of the stand was destroyed by the wind itself.

Wind triggers an outbreak in a forest stand by adding additional substrate for bark beetle breeding. The defence reaction of broken trees against bark beetle attack is weak, and thus, such trees can serve, during a limited period, as "easy" breeding material. The quality of breeding substrate for I. typographus, the phloem, sharply decreases in broken trees, while it can take 17 months to decrease in uprooted trees (Louis et al. 2014). Even when wind-felled trees are removed from the forest, a "sun effect" can occur. This effect was described as a result of sanitary logging; newly opened forest edges are more likely to be attacked by bark beetles due to higher temperatures at forest edges and root damage causing tree stress, favourable conditions for insect dispersal and higher emission of primary attractants (Peltonen 1999; Kautz et al. 2013). The "sun effect" presumably also occurs after windthrows. The shift in bark beetle infestations from fallen $\operatorname{logs}$ to standing trees at forest edges can take 1 to 3 years (Mezei et al. 2011).

Wet, cold weather in the summers of 1997 and 1998 caused the end of epidemics in the study area (Grodzki et al. 2006). Daily maximum air temperature sums have been used (Fig. 2e) as an additional variable related to the population dynamics of bark beetles (Baier et al. 2007; Chen and Jackson 2015) and the stress level of trees (Allen et al. 2010; Park Williams et al. 2012; Anderegg et al. 2013). The I. typographus population dynamics and related tree infestations can be influenced by the current or previous year's temperature conditions (Stadelmann et al. 2013b; Marini et al. 2013; Marini et al. 2017; Mezei et al. 2017). In our analysis, the current year maximum temperature sums with management variables were chosen as the best approximation of tree mortality caused by bark beetles. This variable showed nonlinear patterns. Trees exposed to direct solar irradiation might reach phloem temperature levels lethal for bark beetles, whereas temperatures below threshold on the other side of the maximum daily sum spectrum are not suitable for brood development. Ideally, meteorological variables should be analysed over a longer time span (Kelly 2016) and include more than one outbreak. In case 
of a longer term observational study, this variable showed clear temperature optimum for bark beetle-caused tree mortality (Mezei et al. 2017). Insect outbreaks are strongly influenced by climate, and insects play critical roles in tree physiology and forest ecosystem disturbance (Anderegg et al. 2015; White 2015).

\section{Conclusions}

We assessed the impact of sanitary management and wind disturbance on subsequent tree mortality in the buffer zone of a national park. In the study area, which included neighbouring no-intervention zones in the Polish territory, the management changed several times during the 11-year period (1990 to 2000), making the area a unique opportunity to analyse sanitary management strategies in forest stands that varied over the outbreak time. Under the outbreak scenario, the role of natural disturbance, sanitary management and seasonal temperature sums outcompeted the role of stand and site variables. When an outbreak is initiated, tree mortality in the buffer zone caused by bark beetles is driven mainly by available resources and temperature conditions. Although precise sanitary cutting is the key measure for bark beetle control, the intensity of the removal of dead trees was positively correlated to tree mortality in the next year. From a nature conservation point of view, buffer zones should provide a bulwark for a protected area against influences from outside of the protected area. In case of natural disturbances in the no-intervention area, neighbouring forest owners outside the park demand action to stop the spreading of bark beetle outbreaks. In this instance, a buffer zone can be an area where the rate of bark beetle outbreak spread can be stopped or at least slowed. Even if all beetle-colonised trees are removed, an influx of beetles from other areas may sustain an outbreak. At the initial stage of an outbreak, sanitary management may prove effective. When a bark beetle outbreak reach an epidemic stage, the rate of sanitary cutting in the buffer zone may lead to large areas that have clear cuts and changed paths for forest succession in the buffer zone (Michalová et al. 2017). In this case, decisionmaking bodies face a tough decision: either they should continue to use sanitary management in the buffer zone or they should look for other solutions, such as changes in the zonation of a protected area. If protection measures in a buffer zone are removed, the core zone (i.e. no management zone) of a national park would directly border managed forests. This would hinder landowners, as they are obliged to take necessary measures against insect outbreaks, while the surrounding no-intervention area do not have such obligations. This scenario would mean higher costs in allowances for affected forest stakeholders, and a potential buffer zone for future threats from outside the national park (e.g. invasive species, fire) would be lost.
Acknowledgements The authors wish to thank the staff of the state forests of Tatranský Národný Park (TANAP) in Slovakia and the staff of Tatrzański Park Narodowy (TPN) in Poland for their cooperation in data collection.

Funding Information The study was funded by the Schwarz fund of the Slovak Academy of Sciences, the European INCO Copernicus project: Integrated risk assessment and new pest management technology in ecosystems affected by forest decline and bark beetle outbreaks (IC15-CT98151), the Grant Agency of the Ministry of Education and the Slovak Academy of Sciences (VEGA 0-160-09) and the Slovak Research and Development Agency (APVV- APVV-0297-12).

\section{References}

Allen CD, Macalady AK, Chenchouni $\mathrm{H}$ et al (2010) A global overview of drought and heat-induced tree mortality reveals emerging climate change risks for forests. For Ecol Manag 259:660-684. https://doi. org/10.1016/j.foreco.2009.09.001

Anderegg WRL, Hicke JA, Fisher RA et al (2015) Tree mortality from drought, insects, and their interactions in a changing climate. New Phytol 208:674-683. https://doi.org/10.1111/nph.13477

Anderegg WRL, Kane JM, Anderegg LDL (2013) Consequences of widespread tree mortality triggered by drought and temperature stress. Nat Clim Chang 3:30-36. https://doi.org/10.1038/nclimate1635

Angst A, Rüegg R, Forster B (2012) Declining bark beetle densities (Ips typographus, Coleoptera: Scolytinae) from infested Norway spruce stands and possible implications for management. Psyche A J Entomol 2012:1-7. https://doi.org/10.1155/2012/321084

Bače R, Svoboda M, Janda P et al (2015) Legacy of pre-disturbance spatial pattern determines early structural diversity following severe disturbance in montane spruce forests. PLoS One 10(9):1-18. https://doi.org/10.1371/journal.pone.0139214

Bače R, Svoboda M, Pouska V et al (2012) Natural regeneration in Central-European subalpine spruce forests: which logs are suitable for seedling recruitment? For Ecol Manag 266:254-262. https://doi. org/10.1016/j.foreco.2011.11.025

Baier P, Pennerstorfer J, Schopf A (2007) PHENIPS - A comprehensive phenology model of Ips typographus (L.) (Col., Scolytinae) as a tool for hazard rating of bark beetle infestation. For Ecol Manag 249: 171-186. https://doi.org/10.1016/j.foreco.2007.05.020

Beudert B, Bässler C, Thorn S et al (2015) Bark beetles increase biodiversity while maintaining drinking water quality. Conserv Lett 8 : 272-281. https://doi.org/10.1111/conl.12153

Burnham KP, Anderson DR, Huyvaert KP (2011) AIC model selection and multimodel inference in behavioral ecology: some background, observations, and comparisons. Behav Ecol Sociobiol 65:23-35. https://doi.org/10.1007/s00265-010-1029-6

Dickie I, Whiteley G, Kindlmann P et al (2014) An outline of economic impacts of management options for Šumava National Park. Eur J Environ Sci 4:5-29

Dochtermann NA, Jenkins SH (2011) Developing multiple hypotheses in behavioral ecology. Behav Ecol Sociobiol 65(1):37-45

Fahse L, Heurich M (2011) Simulation and analysis of outbreaks of bark beetle infestations and their management at the stand level. Ecol Model 222:1833-1846. https://doi.org/10.1016/j.ecolmodel.2011. 03.014

Fox GA, Negrete-Yankelevich S, Sosa VJ (2015) Ecological statistics: contemporary theory and application. Oxford University Press, Oxford

Grodzki W (2016) Mass outbreaks of the spruce bark beetle Ips typographus in the context of the controversies around the Białowieża Primeval Forest. For Res Pap 77:324-331. https://doi. org/10.1515/frp-2016-0033

Grodzki W, Guzik M (2009) Wiatro- i ś niegołomy oraz gradacje kornika drukarza w Tatrzańskim Parku Narodowym na przestrzeni ostatnich 
100 lat. Próba charakterystyki przestrzennej. In: Guzik M (ed) Dlugookresowe zmiany w przyrodzie i uzytkowaniu TPN. Wydawnictwa Tatrzañskiego Parku Narodowego, Zakopane, pp 33-46

Grodzki W, Jakuš R, Lajzová E et al (2006) Effects of intensive versus no management strategies during an outbreak of the bark beetle Ips typographus (L.) (Col.: Curculionidae, Scolytinae) in the Tatra Mts. in Poland and Slovakia. Ann For Sci 63:55-61. https://doi. org/10.1051/forest:2005097

Grodzki W, Starzyk JR, Kosibowicz M (2014) Impact of selected stand characteristics on the occurrence of the bark beetle Ips typographus (L.) in the Beskid Żywiecki Mountains. For Res Pap 75:159-169. https://doi.org/10.2478/frp-2014-0015

Grodzki W, Turčáni M, Jakuš R et al (2010) Bark beetles in the Tatra Mountains. International research 1998-2005-an overview. Folia For Pol Ser A 52:114-130

Hedgren PO, Schroeder LM, Weslien J (2003) Tree killing by Ips typographus (Coleoptera: Scolytidae) at stand edges with and without colonized felled spruce treesPhysiological and biochemical analysis. Agric For Entomol 5:67-74. https://doi.org/10.1046/j.14619563.2003.00164.x

Hilszczański J, Starzyk JR (2017) Is it possible and necessary to control European spruce bark beetle Ips typographus (L.) outbreak in the Białowieża Forest? Res Pap 78:88-92. https://doi.org/10.1515/frp2017-0009

Holeksa J, Zielonka T, Żywiec M, Fleischer P (2016) Identifying the disturbance history over a large area of larch-spruce mountain forest in Central Europe. For Ecol Manag 361:318-327. https://doi.org/10. 1016/j.foreco.2015.11.031

Chen H, Jackson PL (2015) Spatiotemporal mapping of potential mountain pine beetle emergence- - Is a heating cycle a valid surrogate for potential beetle emergence? Agric For Meteorol 206:124-136. https://doi.org/10.1016/j.agrformet.2015.03.006

Jakuš R (1998) A method for the protection of spruce stands againstIps typographus by the use of barriers of pheromone traps in northeastern Slovakia. Anzeiger für Schädlingskd Pflanzenschutz Umweltschutz J Pest Sci 71:152-158. https://doi.org/10.1007/ BF02769004

Jonášová M, Vávrová E, Cudlín P (2010) Western Carpathian mountain spruce forest after a windthrow: natural regeneration in cleared and uncleared areas. For Ecol Manag 259:1127-1134. https://doi.org/10. 1016/j.foreco.2009.12.027

Kautz M, Dworschak K, Gruppe A, Schopf R (2011) Quantifying spatiotemporal dispersion of bark beetle infestations in epidemic and nonepidemic conditions. For Ecol Manag 262:598-608. https://doi.org/ 10.1016/j.foreco.2011.04.023

Kautz M, Schopf R, Ohser J (2013) The "sun-effect": microclimatic alterations predispose forest edges to bark beetle infestations. Eur J For Res. https://doi.org/10.1007/s10342-013-0685-2

Kärvemo S, Van Boeckel TP, Gilbert M et al (2014) Large-scale risk mapping of an eruptive bark beetle - importance of forest susceptibility and beetle pressure. For Ecol Manag J 318:158-166. https:// doi.org/10.1016/j.foreco.2014.01.025

Keele JL (2008) Semiparametric regression for the social sciences. John Wiley \& Sons, Inc

Kelly M (2016) Trends in extreme weather events since 1900-An enduring conundrum for wise policy advice. J Geogr Nat Disasters 6: 1-7. https://doi.org/10.4172/2167-0587.1000155

Keskitalo ECH, Pettersson M, Ambjörnsson EL, Davis EJ (2016) Agenda-setting and framing of policy solutions for forest pests in Canada and Sweden: avoiding beetle outbreaks? For Policy Econ 65:59-68. https://doi.org/10.1016/j.forpol.2015.10.011

Klopcic M, Poljanec A, Gartner A, Boncina A (2009) Factors related to natural disturbances in mountain Norway spruce (Picea Abies) forests in the Julian Alps. Ecoscience 16:48-57. https://doi.org/10. 2980/16-1-3181
Lindenmayer D, Thorn S, Banks S (2017) Please do not disturb ecosystems further. Nat Ecol Evol 1:1-8. https://doi.org/10.1038/s41559016-0031

Louis M, Grégoire J-C, Pélisson P-F (2014) Exploiting fugitive resources: how long-lived is "fugitive"? Fallen trees are a longlasting reward for Ips typographus (Coleoptera, Curculionidae, Scolytinae). For Ecol Manag 331:129-134. https://doi.org/10. 1016/j.foreco.2014.08.009

Macek M, Wild J, Kopecký M et al (2016) Life and death of Picea abies after bark-beetle outbreak: ecological processes driving seedling recruitment. Ecol Appl 27:156-167. https://doi.org/10.1002/eap.1429

Marini L, Lindelöw Å, Jönsson AM et al (2013) Population dynamics of the spruce bark beetle: a long-term study. Oikos 122:1768-1776. https://doi.org/10.1111/j.1600-0706.2013.00431.x

Marini L, Økland B, Jönsson AM, et al (2017) Climate drivers of bark beetle outbreak dynamics in Norway spruce forests. Ecography (Cop) in print. doi: https://doi.org/10.1111/oik.02629

Markovic C, Stojanovic A (2010) Differences in bark beetle (Ips typographus and Pityogenes chalcographus) abundance in a strict spruce reserve and the surrounding spruce forests of Serbia. Phytoparasitica 38:31-37. https://doi.org/10.1007/s12600-0090076-X

Mellor AFP, Cey EE (2015) Using generalized additive mixed models to assess spatial, temporal, and hydrologic controls on bacteria and nitrate in a vulnerable agricultural aquifer. J Contam Hydrol 182: 104-116. https://doi.org/10.1016/j.jconhyd.2015.08.010

Mezei P, Grodzki W, Blaženec M et al (2014b) Host and site factors affecting tree mortality caused by the spruce bark beetle (Ips typographus) in mountainous conditions. For Ecol Manag 331: 196-207. https://doi.org/10.1016/j.foreco.2014.07.031

Mezei P, Grodzki W, Blaženec M, Jakuš R (2014a) Factors influencing the wind-bark beetles' disturbance system in the course of an Ips typographus outbreak in the Tatra Mountains. For Ecol Manag 312: 67-77. https://doi.org/10.1016/j.foreco.2013.10.020

Mezei P, Jakus R, Blaženec M et al (2011) Population dynamics of spruce bark beetle in a nature reserve in relation to stand edges conditions. Folia Oecologica 38:73-79

Mezei P, Jakuš R, Blaženec M et al (2012) The relationship between potential solar radiation and spruce bark beetle catches in pheromone traps. Ann For Res 55:243-252

Mezei P, Jakuš R, Pennerstorfer J et al (2017) Storms, temperature maxima and the Eurasian spruce bark beetle Ips typographus-An infernal trio in Norway spruce forests of the Central European High Tatra Mountains. Agric For Meteorol 242:85-95. https://doi.org/10. 1016/j.agrformet.2017.04.004

Michalová Z, Morrissey R, Wohlgemuth T et al (2017) Salvage-logging after windstorm leads to structural and functional homogenization of understory layer and delayed spruce tree recovery in Tatra Mts., Slovakia. Forests 8:88. https://doi.org/10.3390/f8030088

Montano V, Bertheau C, Doležal P et al (2016) How differential management strategies affect Ips typographus L. dispersal. For Ecol Manag 360:195-204. https://doi.org/10.1016/j.foreco.2015.10.037

Müller J, Bußler H, Goßner M et al (2008) The European spruce bark beetle Ips typographus in a national park: from pest to keystone species. Biodivers Conserv 17:2979-3001. https://doi.org/10.1007/ s10531-008-9409-1

Müller M (2011) How natural disturbance triggers political conflict: bark beetles and the meaning of landscape in the Bavarian Forest. Glob Environ Chang 21:935-946. https://doi.org/10.1016/j.gloenvcha. 2011.05.004

Netherer S (2003) Modelling of bark beetle development and of site- and stand-related predisposition to Ips typographus (L.) (Coleoptera; Scolytidae): a contribution to risk assessment. Dissertation thesis BOKU, Vienna, p. 98

Netherer S, Nopp-Mayr U (2005) Predisposition assessment systems (PAS) as supportive tools in forest management—rating of site and 
stand-related hazards of bark beetle infestation in the High Tatra Mountains as an example for system application and verification. For Ecol Manag 207:99-107. https://doi.org/10.1016/j.foreco.2004. 10.020

Nikolov C, Konôpka B, Kajba M et al (2014) Post-disaster forest management and bark beetle outbreak in Tatra National Park, Slovakia. Mt Res Dev 34:326-335

Nováková MH, Edwards-Jonášová M (2015) Restoration of CentralEuropean mountain Norway spruce forest 15 years after natural and anthropogenic disturbance. For Ecol Manag 344:120-130. https://doi.org/10.1016/j.foreco.2015.02.010

Økland B, Berryman A (2004) Resource dynamic plays a key role in regional fluctuations of the spruce bark beetles Ips typographus. Agric For Entomol 6:141-146

Økland B, Bjørnstad ON (2006) A resource-depletion model of forest insect outbreaks. Ecology 87:283-290

Økland B, Nikolov C, Krokene P, Vakula J (2016) Transition from windfall- to patch-driven outbreak dynamics of the spruce bark beetle Ips typographus. For Ecol Manag 363:63-73. https://doi.org/10. 1016/j.foreco.2015.12.007

Park Williams A, Allen CD, Macalady AK et al (2012) Temperature as a potent driver of regional forest drought stress and tree mortality. Nat Clim Chang 3:292-297. https://doi.org/10.1038/nclimate1693

Pasztor F, Matulla C, Rammer W, Lexer MJ (2014) Drivers of the bark beetle disturbance regime in Alpine forests in Austria. For Ecol Manag 318:349-358. https://doi.org/10.1016/j.foreco.2014.01.044

Peltonen M (1999) Windthrows and dead-standing trees as bark beetle breeding material at forest-clearcut edge. Scand J For Res 14:505511. https://doi.org/10.1080/02827589950153989

R (2011) R development core team. In: R A Lang. Environ. Stat. Comput. Vienna. http://r-project.org

Raffa KF, Gregoire J, Lindgren BS, Gre J (2015) Natural history and ecology of bark beetles. Bark beetles: biology and ecology of native and invasive species. pp. 1-40

Rosen J (2016) A forest of hypotheses. Nature 536:239-241

Seidl R, Müller J, Hothorn T et al (2015) Small beetle, large-scale drivers: how regional and landscape factors affect outbreaks of the European spruce bark beetle. J Appl Ecol 53:530-540. https://doi.org/10.1111/ 1365-2664.12540

Shadish WR, Zuur AF, Sullivan KJ (2014) Using generalized additive (mixed) models to analyze single case designs. J Sch Psychol 52: 149-178. https://doi.org/10.1016/j.jsp.2013.11.004

Shafer CL (1998) US National Park buffer zones: historical, scientific, social, and legal aspects. Environ Manag 23:49-73. https://doi.org/ $10.1007 / \mathrm{s} 002679900167$

Schroeder LM, Lindelöw $\AA$ (2002) Attacks on living spruce trees by the bark beetle ips typographus (Col. Scolytidae) following a stormfelling: a comparison between stands with and without removal of wind-felled trees. Agric For Entomol 4:47-56. https://doi.org/10. 1046/j.1461-9563.2002.00122.x

Sproull GJ, Bukowski M, Mcnutt N et al (2017) Landscape-level spruce mortality patterns and topographic forecasters of bark beetle outbreaks in managed and unmanaged forests of the Tatra Mountains. Polish J Ecol 65:24-37. https://doi.org/10.3161/15052249PJE2017.65.1.003

Stadelmann G, Bugmann H, Meier F et al (2013a) Effects of salvage logging and sanitation felling on bark beetle (Ips typographus L.) infestations. For Ecol Manag 305:273-281. https://doi.org/10.1016/ j.foreco.2013.06.003

Stadelmann G, Bugmann H, Wermelinger B et al (2013b) A predictive framework to assess spatio-temporal variability of infestations by the European spruce bark beetle. Ecography (Cop) 36:1208-1217. https://doi.org/10.1111/j.1600-0587.2013.00177.x

Svoboda M, Fraver S, Janda P, et al (2010) Natural development and regeneration of a Central European montane spruce forest. For Ecol Manage 260(5):707-714
Svoboda M, Janda P, Bače R et al (2014) Landscape-level variability in historical disturbance in primary Picea abies mountain forests of the Eastern Carpathians, Romania. J Veg Sci 25:386-401. https://doi. org/10.1111/jvs.12109

Szewczyk J, Szwagrzyk J, Muter E (2011) Tree growth and disturbance dynamics in old-growth subalpine spruce forests of the Western Carpathians. Can J For Res 41:938-944. https://doi.org/10.1139/ x11-029

Švajda J, Koróny S, Zieba A, Adamski P (2016) Perceptions of natural disturbance in Tatra National Park, Poland. For J 62:105-109. https://doi.org/10.1515/forj-2016-0011

Thom D, Rammer W, Seidl R (2017) Disturbances catalyze the adaptation of forest ecosystems to changing climate conditions. Glob Chang Biol 23(1):269-282

Thom D, Seidl R, Steyrer G et al (2013) Slow and fast drivers of the natural disturbance regime in Central European forest ecosystems. For Ecol Manag 307:293-302. https://doi.org/10.1016/j.foreco. 2013.07.017

Thorn S, Bässler C, Bußler H et al (2016) Bark-scratching of storm-felled trees preserves biodiversity at lower economic costs compared to debarking. For Ecol Manag 364:10-16. https://doi.org/10.1016/j. foreco.2015.12.044

Thorn S, Bässler C, Svoboda M, Müller J (2017) Effects of natural disturbances and salvage logging on biodiversity-Lessons from the Bohemian Forest. For Ecol Manag 388:113-119. https://doi.org/10. 1016/j.foreco.2016.06.006

Trotsiuk V, Svoboda M, Janda P et al (2014) A mixed severity disturbance regime in the primary Picea abies (L.) Karst. forests of the Ukrainian Carpathians. For Ecol Manag 334:144-153. https://doi. org/10.1016/j.foreco.2014.09.005

Trzcinski MK, Reid ML (2008) Effect of management on the spatial spread of mountain pine beetle (Dendroctonus ponderosae) in Banff National Park. For Ecol Manag 256:1418-1426. https://doi. org/10.1016/j.foreco.2008.07.003

Wermelinger B (2004) Ecology and management of the spruce bark beetle Ips typographus - a review of recent research. For Ecol Manag 202:67-82. https://doi.org/10.1016/j.foreco.2004.07.018

White TCR (2015) Are outbreaks of cambium-feeding beetles generated by nutritionally enhanced phloem of drought-stressed trees? J Appl Entomol 139:567-578. https://doi.org/10.1111/jen.12195

Wild J, Kopecký M, Svoboda M et al (2014) Spatial patterns with memory: tree regeneration after stand-replacing disturbance in Picea abies mountain forests. J Veg Sci 25:1327-1340. https://doi.org/ 10.1111/jvs. 12189

Wood SN (2006) Generalized additive models: an introduction with R. Chapman and Hall/CRC, Boca Raton

Zeppenfeld T, Svoboda M, DeRose RJ et al (2015) Response of mountain Picea abies forests to stand-replacing bark beetle outbreaks: neighbourhood effects lead to self-replacement. J Appl Ecol 52: 1402-1411. https://doi.org/10.1111/1365-2664.12504

Zielonka $\mathrm{T}$ (2006) When does dead wood turn into a substrate for spruce replacement? J Veg Sci 17:739. https://doi.org/10.1658/11009233(2006)17[739:WDDWTI]2.0.CO;2

Zielonka T, Malcher P (2009) The dynamics of a mountain mixed forest under wind disturbances in the Tatra Mountains, central Europe - a dendroecological reconstruction. Can J For Res 39:2215-2223. https://doi.org/10.1139/X09-130

Zuur AF, Ieno EN, Walker NJ et al (2009) Mixed effects models and extensions in ecology with R. Springer, New York

Zýval V, Křenová Z, Kindlmann P (2016) Conservation implications of forest changes caused by bark beetle management in the Šmava National Park. Biol Conserv 204:1-9. https://doi.org/10.1016/j. biocon.2016.11.001 